\title{
Emotions and Illocutionary Acts Used by Polytechnic Students in Describing Online Learning Issue
}

\author{
Zainal Arifin Renaldo \\ Politeknik Caltex Riau, Pekanbaru, Riau, Indonesia \\ email: zainal@pcr.ac.id
}

\begin{abstract}
:
As COVID-19 Pandemic hit the world, many fields of life need to face some changes. One of the affected areas is academic activity. Since the beginning of the outbreak, academic activity has been switched from class meeting to online meeting. There are various reactions towards the change of academic behavior among students. This article is aimed at classifying the emotions carried out in illocutionary acts used by the students of Politeknik Caltex Riau in regards to online learning issue which manifest in their writing. This research is a descriptive qualitative analysis in which data were collected from students' essay writing under the selected topic. From 30 articles of students' essay writing, 59 sentences were taken as data source. In analyzing the emotional classification, Goleman's theory of emotional intelligence is used. Together with this theory, Speech Acts Theory by Yule and Illocutionary Acts Theory by Searle are used. The result of the study shows that there are four kinds of illocutionary acts used by the students in their writing with expressives appeared to be the most frequent illocutionary acts followed by representatives, directives and commissives respectively. There are five emotional classifications manifest in students' writing i.e. love, anger, enjoyment, sadness, and irritability.
\end{abstract}

\section{Keywords: Illocutionary acts, Emotions}

\section{INTRODUCTION}

As COVID-19 Pandemic hit the world in early 2020, many aspects of human's life are affected. It affects us not only financially, but also to the way we live our life. According to World Health Organization official website, there have been 94,124,612 confirmed cases of COVID-19 including $2,034,527$ deaths globally with 917,015 confirmed cases in Indonesia alone (covid19.who.int). The worldwide society is pushed to be adaptive with the new way of live that often be called as new normal. This change of behavior also happens in education system. Regularly, class is conducted face to face which means teaching and learning activity are done in a class, laboratory, or ELT-Lectura, Vol 8, No 1, February 2021 other forms of rooms that gather all people in one place. But since this pandemic, academic activity has been switched from class meeting to online meeting. This kind of system is not something among academia. Even some institution provides long distance class that is conducted via online learning. Although online class system has been implemented in many education institutions, it was totally different since it was not done massively by almost every schools and universities like what is happening nowadays.

The new academic system that is online-based has been coming with various responses. This new system pushes teachers and students to reconcile with every obstacles happens during online class, and of course it 
comes with a price. Many reactions come as the result of online learning. This reaction manifests in various form of objection commencing from status in social media to verbal complaints given either by students, teachers, or even parents.

Delivering objection is part of communicating emotions. According to Ojomo (2004), communication is the process of sharing ideas, feelings, thoughts and messages with others. Rothwell (2004) views communication as a transactional process of exchanging understanding with our surroundings. From the definitions given, it can be understood that communication is an attempt to exchange thoughts, information, emotion, as well as ideas that will always happen in our daily life. People live to exchange these qualities as it is an integrated part of our role as social creatures.

Speaking of communication itself, one common tool used to support this transaction is language. The use of language in communicating an idea or thought can be manifested in any form. It can appear both in oral or written form. People communicate their ideas by producing utterances. These utterances can appear in the form of questioning, requesting, thanking, ordering, stating, etc. The utterances produced perform meaning from which speech acts manifest.

Speech act is an action performed via utterances (1996). It can be considered as doing an action through language since it carries speaker's communicative intention in producing an utterance. Speech act is classified into three different acts in delivering this actions i.e. locutionary act, illocutionary act, and perlocutionary act.

According to Yule (1996), locutionary act is the basic form of utterance in the production of meaningful linguistic expression. It is a meaning which explains or informs something clearly without any intention or other interpretations. To the extent when someone is saying "there will be traffic jam in the highway, he is literally producing a sentence of which the meaning is based on reference to particular traffic jam and highway. Locutionary act usually manifests in statement, declaration, or news narration.

Searle (1976) elaborates illocutionary as an act used to achieve communicative objective such as ordering, asking, requesting, advising, etc. He classifies illocutionary act into five categories.

The first one is representative which commits the speaker to the truth of the expressed proposition. This act caries out a truth value. They express the speaker's belief in which it includes asserting, claiming, conducting, reporting, and stating.

Directive is a kind of speech act that represents speaker's attempts to make the addressee to perform something in action. Advice, commands, orders, questions, and requests are the examples of this speech act. It leads to an extent the addressee will do as the result of the command they receive from the speaker. By producing an utterance containing this speech act, speaker will create a condition in which the addressee will do an action as the result of comprehending the intention carried out in the utterance.

The type of speech act which commits the speaker to some future course of action is commissive. It expresses speaker's intention to perform some actions such as offers, pledges, promises, refusals, and threats. The difference between this speech act and the previous one is the speaker who will be performing an action after he or she produced the utterance.

Expressive is a kind of speech act which aims to express or to perform speaker's psychological attitude implied in 
the utterances such as joy, sorrow, like or dislike. The function of this category covers the area of thanking, blaming, congratulating, praising, and apologizing. Most of our daily conversation contains this speech act as it is aimed at delivering our thoughts upon something.

The last one is declarative. This type of speech act serves function to create immediate change in some current state of affairs. Speakers perform their utterances to announce or to declare in order to make addressee accept to what has been delivered. It includes declaring something, excommunicating, terminating, and nominating. One of the examples of declarative is employment termination which can be delivered in oral or written form.

When an utterance is produced, it creates an effect on the listener. Saying something will often, or even normally produce certain consequential effects upon the feelings, thoughts, or actions of the audience, or of the speaker, or of other persons (Austin, 1962).

Speaking of meaning, of course we also need to discuss context. The central topics of linguistic pragmatics are those aspect of meaning which are dependent on context (Cruse, 2006). This means, context is principal in pragmatic analysis since it focuses on the meaning each utterance produced and how the speaker's utterance becomes the integrated part in this interaction. Leech (1983) states that context is relevant aspect of the physical or social setting of utterance. Context becomes a background knowledge shared by the speaker and listener. The cooperation between the two results to understanding of meaning conveyed through the utterance. When someone says "what time is it?" to his late coming best friend, it will totally carry different meaning when this utterance is delivered to a stranger. Therefore, context is important for it provides knowledge to every utterance produced.

Another element that is almost impossible to be disregarded in communication is the existence of emotion. Human beings utter something while communicating also in an attempt to express their emotion. Emotion refers to feeling and thoughts, a biological condition and a series of tendency to perform an action. Goleman (1999) classifies emotions into eight categories i.e. (1) anger: hatred, bitterness, violence, disturbed, insulted, irritated, hostile, rampage and annoyed; (2) sadness: hurt, selflove, gloomy, melancholic, lonely, desperate, rejected, and depressed; (3) fear: worried, afraid, nervous, hesitant and vigilant; (4) enjoyment: happy, satisfied, cheerful, amused, amazed and excited; (5) love: acceptance, friendship, trust, kindness, respect, and affection; (6) surprise: surprised, amazed, stunned; (7) irritability; disgust, hate (8) shame: guilty, regret.

Human in this circumstance, express their emotion through language. The expression produced carries out what they have in mind and in feeling. The expression of emotion is the nature of human being whether they feel happy or sad, excited or hopeless, emphatic or disgusted, and this can be seen from the way they deliver the utterances.

In this research, the object of the study is the students' essay writing. As mentioned previously, the new system of learning applied during COVID-19 Pandemic is online based. This system comes with various reactions, be it rejections or acceptance. Some students even stated that they prefer the academic activity during pandemic to be cancelled since this is far from an ideal class they have in mind. 
This research is aimed at investigating the following objectives: (1) investigating out the type of Illocutionary act used by the students in essay writing with the topic online learning; (2) identifying the most frequent Illocutionary act used by the students in their essay writing; (3) identifying the emotions carried out in the essay writing regarding the online learning issue.

The novelty of this research lies on the perspective of the use of language to analyze behavior in regards with response towards some issues. This research is beneficial not only for fellow researchers, but also for readers who need to make a policy or decision especially in education field. By investigating language, we can determine whether the current system that is being applied effective or not.

It is expected that from this research, academic institution can identify what are the most common issue about online learning that exist among students, so that in the future, an ideal solution can be obtained, or in the least effort, students can feel that their institution does not only conduct academic activity to keep the business running, but also show an attempt to consider students' demand.

\section{METHOD}

This research applied descriptive qualitative approach. According to Vanderstoep and Johnston (2009), qualitative research is a method that aims to produce narrative or textual descriptions of the phenomena under study.

In obtaining the data on the students' opinion towards the issue of online learning, some steps were conducted. 30 sophomore students coming from 2 different study programs of Politeknik Caltex Riau participated in this research. They were first requested to write an essay writing with the topic online learning during COVID-19 Pandemic. They were asked to express their opinions in the essay writing. Each of the essay writing was then analyzed by extracting the sentences which contains students' opinion or description about online learning. 59 sentences in the essay writing were taken as data to be analyzed. The collected data were then analyzed in order to classify the type of illocutionary acts manifest in each sentence. In the process of analysis, Searle's classification of illocutionary acts was applied. After the type of illocutionary acts was obtained, each sentence was analyzed by applying the classification of emotion proposed by Goleman (1999). The frequency of both illocutionary acts type and emotion was later presented in the form of chart.

\section{FINDINGS AND DISCUSSION}

The analysis of the data starts with classifying the Illocutionary act manifests in the sentence from the essay writing. From 30 essays collected, 59 sentences were considered representative to be analyzed. The analysis is presented in the following analysis.

\section{Representative}

There are 11 sentences containing representative Illocutionary act, such in:

1. Some students complain about online learning program.

2. The effectiveness of learning process decreases.

3. The main method of teaching is like story telling.

4. Unfortunate students cannot afford themselves for that kind of learning.

5. Online learning is not effective for Indonesian people.

6. There are many students who have difficulty in learning online.

7. Students almost get nothing from learning online. 
8. It is impossible to do lab practice using online methodology.

9. Some teachers don't teach well in online class.

10. It's not only students who hate online study, lecturers also hate it because they must do extra work.

11. Students don't only need to study but also socialize with their friends face to face, not virtually.

12. Many of my friends look so disappointed with this learning system.

13. This online stuff is only suitable in countries with good quality, not like Indonesia.

From all the data above, it is observed that students express their belief upon a value. As explained previously, representative is the kind of speech act that commits the speaker to the truth of the expressed proposition which carries out a truth value. In data (1), (4), (6), (9), (10), (12), students expressed their proposition in the form of reporting. The act of claiming can be seen from data (2), (3), (5), (7), and (12). Meanwhile in data (8) and (11), it can be drawn from the meaning from the sentences that students are asserting their belief.

\section{Expressive}

31 data were classified as expressive, such in:

1. This learning program is just like covid which is depressing.

2. Students feel bored with online learning because we don't study like normal day.

3. Studying online is hard to do because we have so many lacking issues.

4. Student's quality will decrease because they cannot understand fully.

5. This learning method affects students in bad way.

6. E-Learning made the time wasted.

7. Learning online makes student spend more because besides they have to pay tuition fee, they also have to buy internet quota.

8. Online learning is expensive and not effective.

9. E-Learning made the time management became better because no time is wasted as result of traveling to campus and back home.

10. Most lecturers don't teach during online class.

11. It is such a waste of time.

12. Studying with this style is stressful because we have so many homeworks.

13. Some subjects are hard to understand if we do online learning.

14. We became more stupid because of this program.

15. Studying online makes me want to break from college.

16. Doing lab work via online is like watching a boring series.

17. Online learning with offline network are like two hells combined together.

18. Online learning create good entrepreneur not a good student.

19. Studying with E-learning is very expensive because you just get homework and power point slides.

20. It's a shame some lecturers don't even teach properly during online class.

21. Online learning makes us easier to study without attending the class.

22. It's shocking that we keep doing this learning style when everyone is not happy with that.

23. I believe the quality of students became bad because of they cannot join regular class.

24. I think people are too negative in responding online learning, it's not too bad though.

25. I miss my friends in college.

26. I can't imagine many of my friends who are poor have to spend more on quota. 
27. Sometimes I'm thinking, what if I can only meet them in semester 1, and meet them again only in graduation day.

28. I wish our government not only think about vaccination but also the quality of our education.

29. People may hate this, but I love studying online because I feel more relaxed.

30. This whole thing is just stupid.

31. I'm even more sick not because of the virus, but because I'm feeling like a prisoner.

Expressive is the type of speech act that expresses a psychological attitude or state in the speaker. From the data above, the expression of praising appears in data (18), (21), and (29). It is seen that each of the datum contains meaning that students saw online learning from another perspective which is in positive way. The three sentences show praise towards online learning as it is considered creating entrepreneurship, easiness in conducting the class, as well as bringing relaxed condition. The rest of the data show different meaning in which all of them carry the sense of blaming. Students expressed their thoughts on online learning and describe it as something that created burden or problems in their academic life. All the data expresses what they feel, either in positive or negative way.

\section{Directive}

There are 11 sentences which contain directive illocutionary act as follows:

1. Teachers must be more creative in learning online.

2. Education must be sensitive to any change of situation because of pandemic.

3. Studying must be in the class or lab.

4. We have to receive this situation if we don't want to be left behind.
5. Maybe campus just need to stop academic activity until covid finish.

6. Study needs to be done in classroom, not google classroom, moreover if it's more than one semester.

7. With so many people infected by covid, can we just be patient and accept that online class is for our good?

8. This covid thing need to be banished soon so we can come back to school.

9. Come on people, online learning is not that bad.

10. why covid??? Why???

11. This virus need to apologize to all of us because we became stupid now.

12. Can I repeat the time that has been gone?

In this type of illocutionary act, speaker shows an attempt to get the addressee to do something. They express speaker's intention for the addressee to perform what they are commanding. From the data above, the appearance of command can be seen in data (1), (2), (3), (4), (5), (6), (8), (11). It is clear that students want something to be done regarding the problem of online learning they are facing. Data (7) and (9) carries the meaning of an advice, while data (10) and (12) intend to show question.

\section{Commissive}

Commissive is the type of speech act which appearance is the least frequent. There are sentences which contain commissive speech act, such in:

1. We don't need need online learning forever like this.

2. I don't need online learning that can only give me many homeworks and little knowledge.

3. We need to go to campus again, we don't need zoom campus.

All the data above contain refusal as it is seen from the verb "don't need" which 
appears in each datum. Students show their rejection towards online learning and it can be drawn from their sentences.

The frequency of illocutionary act can be presented in the following chart.

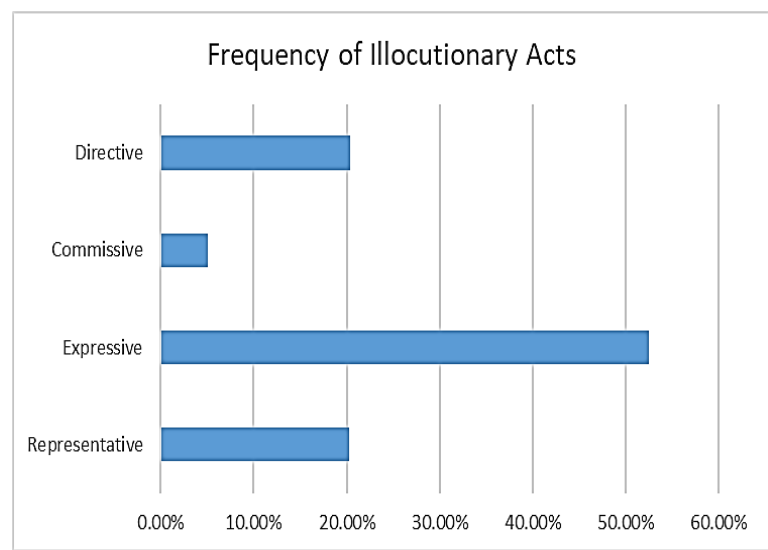

Figure 1. Frequency of Illocutionary Acts in Students Essay Writing

From the chart above, it is seen that expressive appear to be the most frequent type of illocutionary act manifests in students essay writing about online learning, followed by directive, representative, and commissive respectively. This phenomenon is considered normal considering online learning system is something that is relatively new to these students. Especially students who study in polytechnic since they spend more time doing practice in laboratory than in the class which demand them to do it offline. It is hard for these students to just learn something that is supposed to be practiced switch to be online by only watching lecture or even a manual video.

\section{Emotions}

Every sentence produced by the students carries emotion expression. As mentioned in the introduction, Goleman (1999) classifies emotions into eight categories. There are 6 emotions expressions found in the data i.e. irritability, anger, enjoyment, love, shame, and sadness. The sample data are as follows:

\section{Sentences showing the emotion of irritability}

1. This learning method affects students in bad way

2. Education must be sensitive to any change of situation because of pandemic.

3. Learning online makes student spend more because besides they have to pay tuition fee, they also have to buy internet quota

4. It is impossible to do lab practice using online methodology.

5. I believe the quality of students became bad because of they cannot join regular class.

\section{Sentences showing the emotion of anger}

1. It is such a waste of time.

2. Online learning with offline network are like two hells combined together.

3. It's not only students who hate online study, lecturers also hate it because they must do extra work.

4. This covid thing need to be banished soon so we can come back to school.

5. This whole thing is just stupid.

\section{Sentences showing the emotion of sadness}

1. I miss my friends in college.

2. I can't imagine many of my friends who are poor have to spend more on quota.

3. Sometimes I'm thinking, what if I can only meet them in semester 1, and meet them again only in graduation day.

4. Can I repeat the time that has been gone?

5. Many of my friends look so disappointed with this learning system. 


\section{Sentences showing the emotion of enjoyment}

1. E-Learning made the time management became better because no time is wasted as result of traveling to campus and back home.

2. People may hate this, but I love studying online because I feel more relaxed.

\section{Sentences showing the emotion of love}

1. We have to receive this situation if we don't want to be left behind.

2. Online learning create good entrepreneur not a good student.

3. Online learning makes us easier to study without attending the class.

4. I think people are too negative in responding online learning, it's not too bad though.

5. With so many people infected by covid, can we just be patient and accept that online class is for our good?

\section{Emotion Classification}

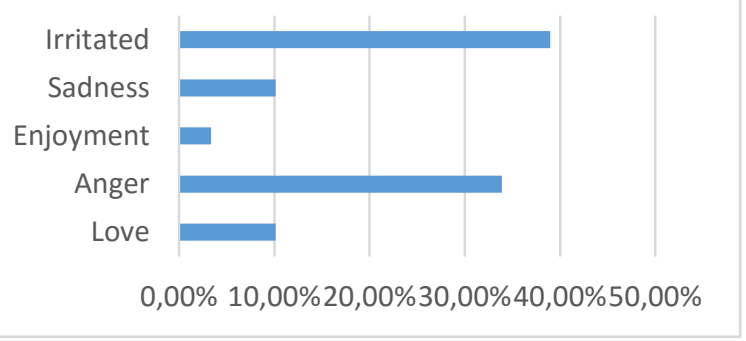

Figure 2. Emotion Classification

From this chart, it is seen that irritability appears to be the most frequent emotion in students' essay writing with $38.98 \%$ occurrence followed by anger $33.89 \%$, sadness and love $10.16 \%$, and enjoyment $10.16 \%$. This analysis shows that most students feel irritated by the online learning that they are facing during pandemic.

\section{CONCLUSION}

After conducting the analysis on the selected data, the writer found there are four types of illocutionary acts in students essay writing describing their opinion about online learning during COVID-19 Pandemic i.e. expressive, representative, directive, and commissive with expressive to be the highest in frequency which is $52.50 \%$. Along with the analysis on the illocutionary acts, the most frequent emotion to appear in the data is irritability which is $38.98 \%$.

From this findings, it can be concluded that most students feel irritated with online learning which is shown through their expression in the essay writing. This is also to show that language analysis can be done to obtain fundamental information related to policy or regulations. Moreover, when it comes to education field. This kind of research can be used as data for institution to make improvement. From this research, it can be inferred that academic institution including teachers and lecturers must be aware of this inconvenience expressed by the students in order to find better way in conducting academic activity for the betterment of students' learning quality.

\section{REFERENCES}

Cruse, A. (2006). A Glossary of Semantics and Pragmatics. Edinburg Press Ltd.

Goleman, D. (1999). Kecerdasan Emosional. Gramedia Pustaka Utama.

Leech, G. (1983). Principles of Pragmatics. Longman Inc.

Ojomo, O. . (2004). Communication: theory and practice. In Language, Communication and Study Skills (pp. 77-95). Covenant University.

Rothwell, J. . (2004). In thw company of others: An Introduction to 
communication. McGraw-Hill.

Searle, J. . (1976). A Classification in Illocutionary Acts. Cambridge University Press.

Vanderstoep, S. W., \& Johnston, D. D. (2009). Research Methods for Everyday Life, Blending Qualitative and Quantitative Approaches. Jossey-Bass.

Yule, G. (1996). Pragmatics. Oxford University Press. 